\title{
ONE WAY TO TEACH HISTORY THROUGH ARTIFACTS
}

\author{
Amy Absher \\ SAGES Fellow in History \\ Case Western Reserve University
}

It was the sixth week of the quarter at the University of Washington. The students in my undergraduate seminar on the United States in the 1950s already had written three papers: two primary-source analysis papers and a research paper of about five pages. They had participated in five library workshops and dozens of classes centered on the history and documents of the 1950s. The papers, the classes, and the workshops had been preparation for this moment. I gathered the students together in one of the library's instruction rooms and explained that their final project for the class was called "The Artifact." Essentially, each of them would receive a sealed envelope containing a primary source. Their mission would be to research the artifact they received. After I handed out the envelopes and they had a chance to look at them, I gave them one minute to switch or, if they wanted, to select one of the remaining sealed envelopes.

Most of the students used the class time that first day to begin a research plan. One wrote, "I had been handed my artifact, [a photo of] the Florence Crittenton Home for Unwed Mothers. Now the real problem began, what was I going to do with it?" She started by looking for opinion polls or articles that would answer her research question: "What was it like to be unwed and pregnant in the 1950s?" Initially, she found no information on this topic until she learned about "one very important research tool, [searching terms] you have to use that would have been used in the time period you are searching." For example, "teenage pregnancy" would not work. Instead, she realized that when searching databases she had to think like a person in the 1950s and use terms such as "unwed mother." The paper ultimately focused on the organizations that existed to help and house "unwed mothers" and their role in agitating for sex education classes for teenage girls. "I found that for my research, primary sources were more useful than secondary," she concluded. "On my works cited page, I have only one secondary source. I think the high degree of social concern and emotional distress suffered by the young women represented in this artifact is best described through firsthand accounts."

I think every history instructor dreams of building a better final paper assignment. Frequently as instructors, we feel limited to assigning book reviews, essays based on course readings, or a research paper. When we assign these projects, too often we learn that students are not doing the readings or we dread having to do Google searches to check for plagiarism. We all want to create assignments that evaluate students' abilities to demonstrate their knowledge of historical facts, to analyze and bring together 
historical evidence, and to write proficiently about their research. ${ }^{1}$ We know that when students care about what they are writing, then their papers improve. But how can we create such assignments while maintaining rigor? In this essay I would like to explain what it was like for me to abandon conventional assignments and design something new, the limitations of such a project, and the advantages for the instructor and students.

\section{The Assignment Structure}

In creating this assignment, I hoped to combine the best part of the research paper (which gives students the chance to learn history actively through library work) and the final exam (which tests knowledge and skills). "The Artifact" assignment came in two parts. The first was the research paper itself. I asked students to begin their thinking process by asking questions of their artifacts. Examples of those questions were:

What does this source teach us about the 1950s?

What does this source teach us about the people, their perspectives, and their motivations in the $1950 \mathrm{~s}$ ?

Does this source represent a change or a transition of some kind?

Where does this source fit in the timeline of the decade?

How does this source relate to what came before it or what came after it?

Giving students these questions and discussing them with students was critical to helping them develop research plans and eventually thesis statements.

I made it clear to students that there was more than one way to interpret any of the artifacts, that they should not try to guess my interpretation of the artifact, and that they were not required to write solely on the artifact. Rather, I asked them to create a work in which the artifact was the starting point and was used as a source in the final paper. This is not to suggest that the project lacked structure. On the contrary, the final project had to make use of a minimum of five primary sources in addition to the artifact. Three of the primary sources had to be from a newspaper or magazine. There was no minimum to how many secondary sources from which the students could draw, but I stressed that in terms of creating an argument, primary sources worked best. In addition, students were allowed to draw from course materials, particularly if they needed help establishing chronology. Finally, because one objective of the assignment was to have students use the university's library collection, I limited them to no more than one source derived from electronic media not owned or subscribed to by the university library.

${ }^{1}$ Frederick D. Drake and Lawrence W. McBride, "Reinvigorating the Teaching of History through Alternative Assessment," The History Teacher, 30 (February 1997), 147-173. 
The second part of the assignment was an essay titled the "Footprints Essay" that asked students to reflect on their research process. Students have too few opportunities to examine themselves as intellectuals and to recognize that the finished paper is as much about their success as it is about their false starts and misassumptions. As with the research paper portion of the assignment, again I asked students to consider a series of questions as a pre-writing exercise:

What search terms, libraries, and databases did you find most useful and which were the least useful?

How did your understanding of the artifact change as you did your research?

What were the limitations of your research?

Was there a moment when your understanding of history changed forever?

The benefit of the "Footprints Essay" is that students become aware of their thinking process and take ownership of their work. Much like asking students to show their work in a math class, the "Footprints Essay" made it possible for students to receive credit for the work they put into writing and researching the paper. In addition, the "Footprints Essay" reduced the possibility of plagiarism because students had to explain how they arrived at their thesis statement and how they found their sources.

\section{Difficulties and Limitations}

At times, creating an assignment such as "The Artifact" concerned me. For example, I worried that the assignment would fail completely. To keep students from feeling the same way about the assignment, I organized the entire course around providing a foundation of historical knowledge, research skills, writing techniques, and analytical processes with the goal being the students' success with their artifacts. As a first step to building the class, I asked the university's history librarian to be my teaching partner. She helped me to select and evaluate the artifacts, assuring that they were well-suited to the university's collections. In addition, she offered a series of inclass mini-library workshops for students. For example, in the week we discussed the murder of Emmett Till and the civil rights movement, the library workshop focused on researching race. In all, she presented five workshops.

Many of the students wrote about their library experience in their "Footprints Essays." One explained, "When I first received my artifact I thought it was horrible and that I had to go to special collections to see it." Another lamented that "Most of the books I requested were never found." Still another wrote, "I also went into the Government Publications stacks ... it's a very scary and claustrophobic place that has a weird windyness [sic] feeling when you walk inside." One student summarized his experience by saying, "Everything I found came from the [university] library catalog so it is good to see the tuition I paid my entire college career has paid off in enhancing my education." He added that he had tried the public library system but decided that 
the class's library workshops gave him a better understanding how to use the university's collections. Though students expressed a certain degree of reticence about having to use the library, their essays suggested that the assignment, because it was buttressed by the library workshops, was successful in that the students formed a relationship with their library.

The artifacts that seemed to elicit the best papers came from popular culture or portrayed minority life. For example, The Sears Catalogue artifact resulted in a paper about the growth in shopping malls and the shifts in consumerism that occurred in the 1950s. Similarly, the film Desk Set, which focuses on a group of librarians who felt threatened by computerization, became part of a paper on mechanization in the work force and its impact on the employment of women. In the same way, an advertisement for Modess Feminine Napkins, an etiquette book for African-American girls, and the photo of the home for unwed mothers all inspired papers that had a lot to teach about women and girls in the 1950s. Some other artifacts, such as soldiers' letters from the Korean War, a booklet on manners issued to soldiers being deployed, and a publication loaded with photos of foreign countries issued by Americans for Democratic Change, were popular because they were less about politics inside the country than they were about American foreign policy. In general, the class was unimpressed by political artifacts, such as a postcard from President Eisenhower's campaigns. They interpreted them as not being open-ended enough. Finally, the least successful artifacts proved to be a restaurant menu and a photograph of a popular Seattle hamburger drive-in. Though students doggedly chased down research, too few primary sources discussed changes in American diets. I concluded from the papers that it was an error on my part to allow current discussions of American culture, such as the impact of fast food, to influence my selection on artifacts.

The way the assignment is presented is as important as the preparatory coursework and selecting the artifacts. Students received their artifacts as a group in an instruction room in the library. Five librarians attended the class and walked around the room helping students get started searching databases and thinking about collections. In addition, after students received their artifacts, we did a brief group activity modeled on "speed dating." Students sat in groups of five. They passed their artifacts around the circle. Each person had a look at each artifact for about two minutes. In that time, they wrote down possible research topics that could be done on the artifact. When I rang a bell, they passed the artifact to the next person. By the end of class students had a list of possible topics generated by the group and they had oneon-one tutorials with the librarians. I believe that they would not have been as successful as they were had they simply been issued their artifacts and sent to do their research on their own.

As students worked on their projects, I realized that the biggest obstacle to their success was not a lack of experience in library research or even unfamiliarity with the artifacts. Rather, the students' discomfort with and fears of certain parts of American history were a constant point of discussion in my one-on-one meetings with students. 
For example, a student athlete received an artifact from a gay publication. He wrote, "When I first received my artifact, the first thing that came to mind was why was I stuck with this topic? I thought to myself how in the hell am I going to find research on something I deem morally wrong? In addition, how am I going to be able to write a paper about this topic without putting my own opinions in the paper?" As it turned out, "If it was not for the help of my fellow classmates in the exercise that was conducted on the day we got our artifacts, I would have taken a very different approach in writing my paper." In private, he explained to me that he felt embarrassed checking out books on gay issues from the library and that he was the target of teasing from teammates when they saw the books in his locker. Ultimately, he managed to overcome his initial fears and developed an objective research plan. He centered first on finding a "clear definition of homosexuality in the 1950's." Then he looked "for the reason it was important" and finally for "the reaction of the government and society." $\mathrm{He}$ summarized his experience by writing, "Overall I enjoyed learning [about] something that I don't believe in."

It was not uncommon for students to have little knowledge of the topics they found themselves researching. Inexperience with the areas of history the artifacts represented presented both a teaching and a grading challenge. Before receiving the artifacts, students had six weeks of instruction that provided a foundation of knowledge about the 1950s. Beyond the classroom discussion, a great deal of one-on-one and small-group discussion occurred in my office. I found that having three to five students at a time in my office was the best approach to discussing thesis statements and research strategies. In these meetings, as the athlete noted, students functioned as more than classmates: they gave support, they gave feedback, and they pooled their research and knowledge in such a way that they became one another's teachers.

In grading the assignments, I had to look at the papers as both essays and exams. As essays, students had to meet research criteria outlined in the assignment, create functioning thesis statements, and develop a certain degree of organization. As exams, the papers had to demonstrate knowledge of history, research techniques, and methods central to the class. I looked for evidence that students understood and applied concepts such as change over time and chronology. In the end, the assignment was an intellectual exercise that the majority of students succeeded in completing because they were solving the puzzle the artifact represented and, in so doing, creating a project that prized their creative and their critical thinking skills equally.

\section{Student Evaluation of the Assignment: Three Years Later}

Three years have passed-and I have moved to another university-since that day in the library when I handed students their artifacts. Their initial response was excitement mixed with trepidation. When asked to recall their experiences with the artifact three years later, the feeling for many is one of fondness. "The weird thing is that I do think about the artifact assignment more often than not when I think of 
school," one former student replied when asked to recall her artifact, an etiquette book for "Negro Girls." "I remember how I researched and had to think outside of the box ... I was trying to portray a certain view of my artifact which was about hygiene for African-American girls." The student was not African-American, she knew very little about African-American history, and admitted she had never even contemplated taking an African-American history class prior to receiving her artifact. "The artifact also taught me how to look at all angles and see that not only one thing was affected by what happened but it had a whole range of effects. The lasting influence of what I learned from the assignment that has stuck with me was how to look at all the angles, and then also to think about how it's going to affect the future." After the seminar was over, this student registered for a course on the history of African-American women.

"Actually I do remember that pretty well," another student wrote. Her artifact was the movie poster for the 1951 film A Place in the Sun, which centered on a young man torn between his love of a wealthy woman with social connections and a workingclass woman who is carrying his baby. After viewing the film, the student first thought she might write about the differences between male and female sexuality, but then she settled on comparing the sexual expressions and activities of different classes of women in the 1950s. Her final paper drew heavily on the Kinsey Report and discussed the social perceptions and public opinion regarding the sexuality of upper and workingclasses women. "Interestingly enough," the student recalled, "throughout the years the Kinsey Report has popped up a number of times randomly in discussion or lectures, though it is usually only vaguely or briefly mentioned (I always feel special when it is because thanks to your class I understand the reference)." Besides the details of the Kinsey Report, the student also had a strong recollection of the class's response to receiving the artifacts: “... we were all very interested in comparing our artifacts and later seeing what we were able to produce from it. It was actually one of the most unique ways to generate interest and ... a starting point to writing research papers I've ever encountered."

Currently, this former student is a fifth-grade teacher in a public school south of Seattle. I asked her if she thought the assignment could be used in her classroom. She responded, "Thinking about some of the things we do with kids, there are a lot of similarities, [my school] focuses on the notion of investigating problems/questions to get to an answer/solution." She believed that having a physical object would generate great interest among her students and would allow "them to be creative in deciding which direction they are interested in pursuing. She theorized that the result would be a greater level of investment on the part of the students "since they are the ones who were able to shape and really personalize/tailor their work."

\section{Looking Ahead}

If I do this assignment again, I would change two things. First, many students found the assignment's page limit constricting. I admit that eight pages probably was 
not a generous limit for such a project. One student wrote: "I would say that my overall experience writing this paper has been a positive one. Perhaps given more time and no page restriction this could develop into a very interesting and promising project." Second, I would use the library workshop model to create writing workshops for the class. Several of the students expressed a desire to write well. One explained in his "Footprints Essay" that learning to write in formal voice was the "most important lesson" he took from the course. Although I spent a great deal of time working one-onone with students, I might have done more with discussing writing in class.

Finally, one of the most obvious limitations of the assignment is that it seems uniquely suited to a small seminar class. The amount of time and attention students needed to complete the assignment would support this argument. However, it is not uncommon for instructors to present students in lecture with an artifact such as a coin, a stamp, or an image and model for students how to analyze such a source. I would like to suggest that this technique could be taken further in the following ways. First, every library has a collection of artifacts in maps, movies, Sears Catalogues, and children's books. These items could be placed on course reserve and the students could select from them as a starting point for their papers. Second, an artifact could be issued to each discussion section and each student in that section could research an aspect of the artifact, resulting in a collection of papers that, when taken together, offered a history and analysis of the artifact. Third, following a series of lectures on a topic, students could visit the library and find an item that they believed explains, contradicts, or exemplifies the topics discussed in lecture. The variations on the artifact assignment are endless, but the elements that should remain the same are emphasis on active learning and the idea that creative thinking and critical thinking are interdependent concepts. 